Available online at website :

http://e-journal.adpgmiindonesia.com/index.php/jmie

JMIE: Journal of Madrasah Ibtidaiyah Education, 5(1), 2021, 1-14

\title{
ANALISIS PEMBELAJARAN IPS DI SD/MI DALAM KURIKULUM 2013
}

\author{
Amirah Al May Azizah \\ Universitas Islam Negeri (UIN) Sunan Kalijaga Yogyakarta \\ Email: almayazizah97@gmail.com
}

Submit: 14 Oktober 2020, Revisi: 23 Maret 2021, Approve: 19 Mei 2021

\begin{abstract}
Problematic, that appears in the learning process on the previous curriculum is centered on the teacher (teacher center), with the result that there is no improvisation that causes learners to glued only on the basic materials. In the new curriculum (2013) the learning process began to focus on the learners (student center). This is outlined in the discussion with the analysis of ips learning in elementary school/madrasah ibtidaiah 2013 curriculum. Began from the changes of a new curriculum, which is integratif theme, it is expected the students to be able to be an active individual, creative, critical thinking, have teamwork and could fight in the competition of global. The paper uses library research methods. Collecting data in this study conducted by reviewing a few relevant sources such as books, articles or journal, and other documents. Data analysis technique uses content analysis. The results of research proved that IPS learning in elementary school/madrasah ibtidaiah in the 2013 curriculum is an collection from various aspects, which contains the scientific structure of IPS in elementary school/madrasah ibtidaiah, the development characteristics of students, high-level thinking ability or HOTS (higher orders thinking), financial literacy, literacy in culture and citizenship, digital literacy, and character education
\end{abstract}

Keywords : Eelementary School, Learning IPS, Curriculum 2013

Pengutipan: Amirah Al May Azizah. (2021). Analisis Pembelajaran IPS di SD/MI dalam Kurikulum 2013. JMIE: Journal of Madrasah Ibtidaiyah Education, 5(1), 2021, 1-14. jmie.v5i1.266.

Permalink/DOI: http://dx.doi.org/10.32934/jmie.v5i1.266 


\section{PENDAHULUAN}

Keterampilan pada abad 21 ditandai dengan perkembangan IPTEK media informasi dan komunikasi termasuk pendidikan dan proses pembelajaran. Pendidikan di sekolah dituntut mampu mempersiapkan peserta didik memasuki abad 21, proses pembelajaran di sekolah yang disesuaikan dengan kemajuan zaman. Pembelajaran mulanya terfokus pada pendidik hingga pembelajaran terfokus pada siswa. Prinsip pembelajaran yang terpusat pada peserta didik, dapat menjadikan pembelajaran lebih bermakna karena siswa tidak hanya menyimak pembelajaran saja tetapi lebih merasakan pengalaman pembelajaran secara langsung (Sutrisna, 2012). Konsep pembelajaran dalam kurikulum 2013 menggunakan pendeketan saintifik, yakni pembelajaran yang mengajarkan peserta didik pemahaman bahwa dalam mempelajari berbagai materi dapat dilakukan tidak terbatas waktu dan tempat, anak didik dapat mencari tahu secara individu dalam belajar (Nurdyansyah \& Fahyuni, 2016).

Dalam pelaksanaan kurikulum 2013, peserta didik diberikan kebebasan dalam menyelesaikan persoalan sendiri, serta mampu memahami berbagai permasalahan yang dihadapinya (Sinambela, 2013). Kemampuan siswa dalam bekerja sama merupakan tuntutan yang harus dilakukan oleh tiap siswa pada kurikulum 2013 ini. Keterampilan 4C merupakan empat kompetensi yang harus dimiliki setiap siswa, kecakapan-kecakapan tersebut meliputi berfikir kritis (critical thinking), berkomunikasi (communication), berkolaborasi (collaboration), serta memiiliki kreativitas (creativity). Dalam kurikulum 2013 memiliki ciri khas yang erat kaitannya dengan SKL dan SI (Saharuddin \& Mutiani, 2020).

Pembelajaran IPS di SD/MI pada kurikulum sebelumnya merupakan mata pelajaran yang berdiri sendiri, tidak bersifat tematik-integratif, yang mana pembelajaran IPS hanya fokus pada materi-materi IPS saja. Pembelajaran IPS merupakan serangkaian disiplin ilmu yang saling terintegrasi (Siska, 2016). Proses pembelajaran IPS dalam kurikulum sebelumnya dijenjang sekolah dasar hanya terfokus pada guru, karena kurangnya improvisasi sehingga tidak adanya improvisasi lain yang menyebabkan siswa cenderung merasa bosan dan hanya terpaku pada materi pokok saja.

Dalam kurikulum 2013 ini hadirnya pembelajaran tematik integratif yang terpusat pada siswa diharapkan peserta didik dapat aktif, kreatif, berpikir kritis, bekerja sama, dan berkompetisi dalam kancah global. Sehubungan dengan hal ini, pembaruan dan pembelajaran IPS ditandai dengan kebutuhan dan minat anak, bahan pelajaran lebih banyak fokus terhadap permasalahan sosial, pembelajaran lebih banyak memperhatikan keterampilan, pembelajaran lebih memperhatikan pelestarian keadaan lingkungan sekitar (Susanto, 2014).

Penulisan ini memiliki tujuan untuk menganalisis pembelajaran IPS di SD/MI dalam kurikulum 2013 seperti; struktur keilmuan, karakteristik perkembangan peserta didik, 4C, HOTS, literasi budaya, literasi finansial, literasi digital, literasi budaya dan kewargaan, dan pendidikan karakter. Berdasarkan pernyataan di atas, maka pembelajaran IPS dalam kurikulum 2013 diharapkan tidak hanya sekedar materi dan pengetahuan saja, tetapi yang terpenting proses pembelajaran yang dapat mengarahkan peserta didik menjadi individu yang paham dengan tanggung jawaabnya sebagai warga negara, selain itu juga diharapkan peserta didik 
dapat bekerja sama, dan berkompetisi dalam kancah global. Maka dalam hal ini, peneliti tertarik untuk menganalisis pembelajaran IPS di SD/MI dalam kurikulum 2013.

\section{METODE}

Penelitian ini menggunakan penelitian studi pustaka (library research), yakni jenis penelitian yang mempertemukan data penelitian dari khasanah literatur serta menjadikan 'teks' sebagai objek analisisnya. Teknik pengumpulan data dilakukan dengan mengumpulkan data dari berbagai literature misalnya buku, artikel, makalah, jurnal, dan berbagai karya tulis yang memiliki keterkaitan dengan pembahasan dalam penelitian ini. Adapun analisis data dalam penelitian ini yaitu menggunakan metode analisis konten atau analisis isi. Tujuan dari penggunaan analisis isi ini yaitu untuk mempermudah pembaca dalam memahami intisari dari pembelajaran IPS di SD/MI kurikulum 2013.

\section{HASIL PENELITIAN DAN PEMBAHASAN Pembelajaran IPS di SD/MI}

Ilmu Pengetahuan Sosial atau yang dikenal sebagai IPS merupakan pembelajaran yang menganalisis, dan mempelajari masalah sosial dari berbagai aktivitas dalam kehidupan sosial. Dalam standar isi IPS diharapkan peserta didik mampu memunculkan sikap peka terhadap persoalan yang terjadi di lingkungan masyarakat (Herijanto, 2012). Tujuan dari pembelajaran IPS agar siswa memiliki kepedulian terhadap lingkungan sosialnya melalui pemahaman terhadap nilai kebudayaan, selain itu mampu memahami konsep dasar yang dipelajari dari ilmu sosial, kemudian memahami dari berbagai potensi untuk mengembangkan diri siswa. Pembelajaran IPS melatih anak didik untuk menghasilkan warga negara yang mampu untuk memecahkan masalah berdasarkan pemikirannya serta berdasarkan moral dan nilai yang terbentuk oleh diri-sediri dan lingkungan sekitarnya. Kompetensi dapat dikatakan mampu pengambilan keputusan saat menyelesaikan persoalan. Peduli yaitu memahami realitas sosial dalam menjalankan kewajibannya di lingkungan masyarakat (Rahmad, 2016).

Nilai-nilai yang terdapat dalam pembelajaran IPS di SD/MI yaitu antara lain; nilai teoritis yakni siswa dibina agar mengembangkan daya pikirnya untuk mempelajari realitas kehidupannya, selanjutnya nilai praktis yakni siswa dibina agar peserta didik mampu menghadapi permasalahannya sendiri, kemudian nilai edukasi yakni bahan ajar yang dipelajari dalam pembelajaran IPS tidak serta merta teori, realitas sosial dan data saja, melainkan juga mengangkat permasalahan sosial yang terjadi, melalui pembinaan edukatif tidak terbatas pada pengetahuan saja, namun lebih mendalam dalam perilaku afektifnya (Siska, 2016). Pada jenjang SD/MI, pembelajaran IPS memuat berbagai kajian ilmu seperti; sejarah, kebudayaan (antropologi), ekonomi, hukum, dan letak geografi. 


\section{Pembelajaran IPS dalam Kurikulum 2013}

Dalam kurikulum 2013, pembelajaran IPS diintegrasikan pada kompetensi dasar disiplin ilmu lain yang dihubungkan melalui keterikatan topik atau makna. IPS mempunyai tempat yang sama dengan disiplin ilmu yang lain. Meskipun konsep belajar dilakukan secara tematik, namun kompetensi dasar untuk IPS tetap terpisah dengan kompetensi dasar yang lain. (Meldina, Agustin, \& Harahap, 2020). Adapun tujuan khusus bagi anak didik untuk mempelajari IPS pada kurikulum 2013 ini yaitu membekali peserta didik yang bermanfaat untuk kehidupan masyarakat, kemudian membekali peserta didik agar mampu memecahkan masalah sosial yang terjadi dalam kehidupan sosialnya dalam hal ini maka perlunya mengasah critical thinking peserta didik, membekali peserta didik agar mampu memiliki sikap mental yang positif, serta membekali peserta didik agar memiliki kreativitas yang baik. Dalam kurikulum 2013, KI harus memiliki kualitas yang sama antara pencapaian hard skills dan soft skills.

IPS di SD/MI kurikulum 2013, dilakukan dengan mengintegrasikan konteks kurikulum 2013, demikian sesuai dengan penelitian (Setiana, 2014) yang mengemukakan bahwa pada pendekatan dalam pembelajaran kurikulum 2013, pembelajaran IPS disusun dari beragam disiplin ilmu sosial. Pembelajaran IPS di SD/MI dalam kurikulum 2013 bersifat tematik-integratif, dalam hal ini ada empat macam jenis pendekatan terpadu.

Pendekatan tematik terpadu adalah pendekatan pembelajaran yang mengintegrasikan beragam kompetensi mata pelajaran ke dalam suatu tema (Prastowo, 2015). Pengembangan dalam pembelajaran tematik, dapat mengadaptasi dari suatu topik dari disiplin ilmu tertentu, kemudian dikemas, dikaji hingga diperluas oleh disiplin ilmu yang lain. Demikian penelitian ini mengkaji mengenai pembelajaran IPS di SD/MI pada kurikulum 2013 yang mencakup hal-hal seperti; pembelajaran IPS di SD/MI dalam berbagai hal seperti struktur keilmuan, karakteristik perkembangan peserta didik, HOTS (high, order, thinking, skill) atau berfikir siswa tingkat tinggi, kemudian 4C yaitu critical thinking; communication; collaboration; creativity. Selanjutnya peneliti akan mengkaji mengenai literasi finansial dalam pembelajaran IPS di SD/MI, literasi digital, literasi budaya dan kewargaan. Pendidikan karakter untuk membekali siswa mengenal serta memahami dirinya sendiri dan menanamkan nilai-nilai karakter yang baik.

Berdasarkan penelitian sebelumnya (Subadi, Priyono, Dahroni, \& Musyiyam, 2015) yang membahas tentang indikator yang harus dicapai pendidik dalam mengimplementasikan kurikulum 2013 pada disiplin ilmu IPS adalah pertama, strategi penerapan pembelajaran IPS berbasis lesson study melalui 3 tahap yaitu, perencanaan, observasi, refleksi. Kedua, pemikiran dalam perubahan kurikukum 2013 yang menekankan pada; pendekatan saintifik yang mengembangkan kreativitas siswa, keutuhan pada kecakapan kompetensi keterampilan, sikap dan pengetahuan, keutuhan antara ekstrakulikuler, dan kulikuler. Ketiga, proses pembelajaran pada 2013 yang menekankan pada; tematik terpadu untuk tingkat SD/MI, dan mata pelajaran IPA maupun IPS yang semula terpisah menjadi terintegrasi.

Penelitian lainnya oleh (Meldina et al., 2020) membahas tentang keterkaitan antara IPS dengan Kurikulum 2013 di SD/MI. Hasil penelitian tersebut yaitu pembelajaran IPS dengan penggabungan tema dengan kompetensi dasar mata pelajaran lainnya menunjukkan integrasi 
multidisipliner dilaksanakan dengan memisahkan kompetensi dasar pada disiplin ilmu sehingga tiap pelajaran mempunyai kompetensi dasarnya sendiri. Pada tema dan sub-tema yang akan dipahami selalu memadukan pembelajaran IPS, dan kemudian subtema dilakukan melalui beberapa kegiatan belajar.

Berdasarkan uraian tersebut di atas, penelitian dalam penulisan ini terfokus dalam mengkaji pembelajaran IPS dalam kurikulum 2013 yang mengkaji hal-hal seperti; pembelajaran IPS dengan struktur keilmuan, karakteristik perkembangan peserta didik, HOTS, keterampilan 4C, literasi digital, literasi budaya kewargaan, literasi finansial, dan pendidikan karakter. Berikut merupakan kajian pembelajaran IPS di SD/MI dalam kurikulum 2013:

\section{Struktur Keilmuan}

IPS merupakan penyesuaian dari berbagai struktur keilmuan atau cabang ilmu sosial, seperti antropologi, geografi, sosiologi, hukum, politik, ekonomi, sejarah, dan lain sebagainya (Siska, 2016). Cabang ilmu tersebut memiliki integrasi yang sesuai misalnya geografi memberikan wawasan mengenai letak wilayah, sejarah membahas mengenai peristiwa yang terjadi pada masa lalu, ekonomi membahas mengenai macam-macam kebutuhan manusia, dan lain sebagainya. Maka kompetensi dasar IPS merupakan bagian dari berbagai struktur keilmuan atau cabang ilmu sosial yang kemudian di kemas dalam tema-tema tertentu (Susanto, 2014).

Pada hakikatnya pembelajaran IPS di SD/MI tidak menelaah ilmu-ilmu sosial sebagai cabang ilmu, melainkan sebagai esensi dari berbagai ilmu sosial. IPS sebagai bahan ajar secara garis besar terdiri atas tiga tradisi, yaitu: (1) Citizenship Transmitters. Dimana pembelajaran IPS didasarkan pada pengetahuan, berperilaku baik. (2) Social Science Position, yaitu ilmu-ilmu sosial yang dimaksudkan untuk menciptakan individu yang berkarakter di masa mendatang. (3) Reflektif Inquires, siswa dapat mengembangkan rasional, berfikir benar dalam pengambilan keputusan berdasarkan pengetahuan (Anshori, 2016). Pembelajaran IPS merupakan struktur yang mengembangkan kognitif, afektif, dan kemampuan sosial dalam membentuk individu yang baik (Surahman \& Mukminan., 2017).

\section{Karakteristik Perkembangan Peserta Didik}

Perkembangan individu anak didik ditandai dengan perkembangan fisik psikomotorik, perkembangan sosial emosional, dan perkembangan moral spiritual, perkembangan kognitif intektual. Dalam pembelajaran, potensi dalam individu peserta didik harus dikembangkan (Samio, 2018). Dalam memahami karakteristik perkembangan peserta didik, peran pendidik sangatlah penting bagi proses perkembangannya, tidak hanya pendidik tetapi peran lingkungan keluarga dan teman sebaya juga mempengaruhi perkembangannya. Adapun karakteristik perkembangan yang perlu dipahami oleh pendidik antara lain; mempelajari karakteristik peserta didik dalam belajar agar pendidik dapat mengetahui gaya belajar peserta didik, dan mengetahui bakat minat serta kemampuan yang ada dalam diri siswa. 
Kemudian karakteristik dalam mempelajari karakteristik fisik maupun non-fisik siswa, hal tersebut memiliki tujuan untuk memahami pertumbuhan peserta didik yang mengarah pada fisik maupun non-fisik, karena karakteristik ini berpengaruh pada pencapaian tujuan belajar masing-masing peserta didik (Janawi, 2019). Berdasarkan uraian tersebut, materi IPS di SD/MI pada kurikulum 2013 dalam memahami karakteristik perkembangannya, berkaitan dengan perkembangan peserta didik, misalnya materi ajar mengenai nilai-nilai sosial akan mengoptimalkan perkembangan sosial emosional peserta didik, selain itu materi ajar mengenai nilai karakter yang terkandung dalam setiap proses pembelajaran dapat menumbuhkembangkan perkembangan moral spiritual peserta didik.

\section{HOTS (Higher, Order, Thinking, Skill)}

Perubahan kurikulum 2013 di jenjang SD/MI mengacu pada penerapan proses pembelajaran tematik-integratif dengan pengembangan ketrampilan tingkat tinggi (HOTS) bagi peserta didik. High Order Thinking Skill atau biasa disebut dengan HOTS merupakan kemampuan berfikir tingkat tinggi siswa dalam level pengetahuan yang tinggi dan ditumbuhkan dari beragam konsep seperti mengkategorikan, memanipulasi, menempatkannya pada konteks yang baru, serta menerapkannya terhadap pemecahan masalah (Rahayuningsih \& Rani, 2019).

Berdasarkan teori Taksonomi Bloom terdapat perbedaan tingkatan berfikir yaitu keterampilan berfikir tingkat rendah (LOTS) dan keterampilan berfikir tingkat tinggi (HOTS). LOTS dalam hal ini mencakup hal-hal seperti mengingat, mempelajari, dan mengimplementasikan saja. Sedangkan HOTS mencakup menganalisis (C4), mengevaluasi (C5), dan (C6) mencipta (Simamarta, Lidia, \& Rahmi, 2020). HOTS mencakup kecakapan dalam memecahkan masalah, kecakapan dalam berfikir kritis, kreatif, dan mengambil keputusan (Fanny, 2019). Apabila dikaitkan dengan materi pokok IPS di SD/MI, kemampuan berpikir tingkat tinggi ini salah satu contohnya di kelas IV pada KD 3.4 semester 1 yang didalamnya terdapat stimulus berupa bacaan yang kemudian peserta didik mampu menelaah dan menyimpulkan isi dalam bacaan tersebut. Karena menggunakan istilah 'menelaah' dan 'menyimpulkan', maka dalam kata kerja operasional menurut Bloom kata tersebut termasuk dalam C4 (menganalisis).

\section{Keterampilan 4C}

Perwujudan potensi pembelajaran pada peserta didik di SD/MI pada abad 21 didukung dengan keterampilan yang terdapat pada standar kompetensi lulusan (SKL) di tingkat SD/MI. Ukuran tersebut ialah peserta didik memiliki keterampilan dalam memahami, dan berperilaku secara kritis, inovatif dan mandiri, kolaboratif, dan komunikatif (Peraturan Menteri Pendidikan Kebudayaan 2016 No. 16, n.d.).

Demikian diberlakukannya SKL tersebut, menunjukkan bahwa materi pokok di SD/MI yang salah satunya termasuk pelajaran IPS merupakan suatu langkah agar dapat mengupayakan potensi dan kemampuan peserta didik dalam mengoptimalkan pembelajaran pada abad 21. 
a) Critical Thinking: Proses pembelajaran yang mengajak siswa untuk mengembangkan pemikiran yang kritis dan mampu mengatasi masalah yang rumit. Peserta didik yang memiliki kemampuan dalam berfikir kritis dapat memahami serta memanfaatkan suatu informasi dengan baik (Indraswati, Marhayani, Sutisna, Widodo, \& Maulyda, 2020). Kemampuan dalam mengoneksikan atau menghubungkan suatu informasi dengan informasi yang lain.

b) Creativity: Kemampuan peserta didik dalam mengembangkan, menyampaikan gagasan baru, serta berkreasi. Kreativitas juga diartikan sebagai penciptaan gagasan baru yang belum pernah ada sebelumnya (Budiarti, 2015). Bersikap responsif terhadap suatu gagasan baru dan berbeda. Dalam hal ini juga membuat peserta didik untuk berinovasi terhadap penemuan- penemuan baru sesuai dengan kreativitas masing-masing peserta didik. Dalam perkembangannya, kreativitas dan segala kemampuan siswa sangat perlu untuk dikembangkan, sejalan dengan hal tersebut maka merujuk pada tujuan pendidikan yaitu menumbuhkan keterampilan kognitif peserta didik dalam menghadapi berbagai macam masalah yang terjadi dalam hidupnya, seperti dengan menumbuhkan kecakapan mereka dalam memecahkan setiap masalah yang dihadapinya, dan tentu, hal tersebut memerlukan kemampuan bakat dan kreativitas peserta didik (Munastiwi, 2019).

c) Communication: Kemampuan peserta didik untuk mengomunikasikan suatu pembelajaran baik secara lisan maupun tulisan. Peserta didik yang memiliki keterampilan dalam berkomunikasi dengan baik, mampu menyampaikan pendapatnya dengan kalimat yang jelas sehingga dapat memberikan penguatan orang lain melalui kecakapan berbicaranya (Septikasari \& Frasandy, 2018).

d) Collaboration: Kemampuan peserta didik dalam bekerja sama, berkolaborasi, saling bersinergi dan mampu beradaptasi dalam pembelajaran. Melalui kemampuan kolaborasi, peserta didik mampu membangun perkembangan kognitifnya dalam mengumpulkan informasi serta dapat mengoptimalkan keterampilan mental peserta didik (Funali, 2014).

\section{Literasi Finansial}

Literasi finansial adalah rangkaian aktivitas untuk meningkatkan keterampilan seseorang dalam mengelola keuangan dengan baik. Dalam hal ini literasi finansial mencakup pengetahuan dan keterampilan seseorang untuk mengelola keuangannya dengan bijaksana. Tuntutan keterampilan pada abad 21, setiap individu setidaknya memiliki enam literasi dasar. Salah satunya yakni kemampuan dalam literasi fianansial (Yukarista, 2019). Literasi finansial sangat berkaitan dengan kehidupan kesejahteraan individu. Oleh karena itu sangat penting untuk diajarkan sejak dini atau sejak sekolah dasar.

Literasi finansial di Sekolah Dasar tidak sekedar mengenalkan uang saja kepada peserta didik melainkan belajar pengelolaan keuangan dengan baik, belajar kewirausahaan dan cerdas dalam transaksi keuangan (Laila \& Hadi, 2019). Cara mengajarkan literasi finansial pada peserta didik perlu pengarahan dari semua pihak agar edukasi mengenai pengelolaan keuangan ini dapat terkonsep pada pola pikir anak dan kemudian termanifestasi pada perilaku nyata 
dalam kehidupan sehari-hari. Keluarga merupakan sumber utama yang berperan penting untuk mengajarkan pengelolaan keuangan anak dengan baik. Tidak hanya keluarga, sekolah juga ikut berperan andil dalam menanamkan literasi finansial pada anak (Rapih Subroto, 2016).

Relevansi literasi finansial terhadap IPS di SD/MI adalah IPS memiliki peran dalam menanamkan nilai-nilai literasi finansial dan memberikan edukasi pada peserta didik. Selain hal tersebut, sebagai contoh hal kecil sekolah juga menanamkan nilai-nilai literasi finansial seperti membiasakan anak agar menabung, misalnya guru mengarahkan peserta didik untuk menyisihkan uang jajannya untuk ditabung, dengan menuliskan dalam buku tabungan masingmasing siswa.. Maka dalam hal ini, siswa terbiasa untuk tidak menghabiskan uangnya, dan termotivasi untuk mengelola keuangannya.

\section{Literasi Budaya dan Kewargaan}

Selain enam literasi dasar yang harus dimiliki peserta didik sebagai tuntutan abad 21, salah satunya adalah literasi budaya dan kewargaan, yaitu kemampuam dalam mengenal hingga memahami kebudayaan Indonesia sebagai jati diri bangsa (Nugroho, 2020). Indonesia mempunyai keberagaman budaya, etnis, bahasa, suku dan agama. Indonesia juga merupakan salah satu dari dunia secara luas, maka Indonesia dapat dipengaruhi oleh budaya dari negaranegara lain, akibatnya keragaman yang sudah ada yang dimiliki setiap suku bangsa Indonesia menjadi semakin beragam dan kompleks.

Literasi budaya dan kewargaan penting dipelajari serta disosialisasikan di tingkat sekolah maupun lingkugan masyarakat. Literasi budaya dan kewargaan tidak serta merta untuk melestarikan kebudayaan saja, akan tetapi menjaga jati diri bangsa Indonesia di seluruh dunia. (Kementerian Pendidikan dan Kebudayaan, 2017). Dalam pembelajaran, literasi budaya dan kewargaan merupakan wadah untuk memberikan pengetahuan kepada siswa untuk melestarikan budaya Indonesia serta memberi pemahaman mengenai tanggung jawab sebagai warga negara (Setiawan, 2020).

Penerapan literasi budaya dan kewargaan di sekolah memiliki strategi gerakan literasi budaya dan kewargaan, yang pertama adalah pelatihan guru. (Kementerian Pendidikan dan Kebudayaan, 2017) Memberikan pemahaman keterampilan literasi budaya dan kewargaan dalam pembelajaran dapat membentuk watak dan perilaku siswa yang menghargai, dan memahami, serta merawat kebudayaan persatuan dan kesatuan bangsa.

Dalam pembelajaran IPS di SD/MI penerapan literasi budaya dan kewargaan dapat diberikan melalui bahan bacaan yang bertema budaya dan kewargaan. Hal ini tidak hanya menumbuhkan literasi budaya dan kewargaan, namun juga menumbuhkan literasi baca-tulis siswa (Kementerian Pendidikan dan Kebudayaan, 2017). Selain itu bebarapa materi IPS di sekolah dasar juga dapat menumbuhkan literasi budaya dan kewargaan antara lain materi tersebut adalah materi kelas IV SD/MI tentang keanekaragaman budaya di Indonesia, seperti beragam agama, suku, bahasa yang ada di Indonesia. Hal tersebut dapat dilihat bahwa materi IPS di SD/MI diharapkan mampu menumbuhkan literasi budaya dan kewargaan di Indonesia, 
selain itu menumbuhkan rasa nasionalisme dan toleransi terhadap keragaman budaya di Indonesia.

\section{Literasi Digital}

Literasi digital yaitu keterampilan seseorang dalam mengoperasikan media digital dan media komunikasi. Keberhasilan dalam membangun kemampuan literasi digital merupakan bagian dari indikator yang harus dicapai di bidang pendidikan. (Kementerian Pendidikan dan Kebudayaan, 2017). Dalam hubungannya dengan pembelajaran IPS, literasi digital merupakan sarana untuk pengembangan kognitif siswa pada permasalahn sosial yang ada di lingkungan sekitar secara nyata (Ginanjar, Noviani, Aisyah, Fredi, \& Adila, 2019). Pendidikan, siswa harus dibekali literasi digital sejak dini, misalnya setiap sekolah memberikan muatan lokal dengan mata pelajaran TIK

\section{Pendidikan Karakter}

Pendidikan karakter menjadi syarat utama untuk dapat hidup sukses pada abad 21. Pendidikan karakter merupakan proses untuk membentuk pribadi yang memiliki karakter dalam aspek pikiran, hati, serta perilaku. Pendidikan karakter mengajarkan peserta didik pada pemahaman nilai secara kognitif maupun afektif, kemudian dilaksanakan secara nyata (Latifah, 2014). Pendidikan karakter juga diartikan sebagai pendidikan moral, pendidikan nilai, dan pendidikan akhlak yang memiliki tujuan dalam menumbuhkan kompetensi siswa dalam pengambilan keputusan, dan mengaplikasikannya dalam kehidupan. (Rosidatun, 2018)

Menurut Lickona dalam adanya alasan mengapa pendidikan karakter pada siswa harus ditanamkan yaitu pertama, karena pendidikan karakter adalah strategi untuk membentuk siswa untuk memiliki kepribadian yang baik dalam hidupnya. Kedua, akar dari permasalahan yang umum yang berhubungan dengan masalah moral dan sosial, seperti kekerasan, ketidaksopanan. Ketiga, pengajaran nilai kebudayaan merupakan aspek dari peradaban. Keempat, pendidikan karakter merupakan persiapan terbaik untuk penyesuaian diri di tempat kerja. Kelima, pendidikan karakter merupakan kesiapan siswa agar menghargai orang lain, agar dapat hidup di tengah masyarakat global (Syamsunardi \& Nur, 2019).

Adapun relevansinya terhadap pembelajaran IPS dalam kurikulum 2013 di SD/MI adalah IPS merupakan peranan yang penting dalam mengarahkan peserta didik pada nilai-nilai peilaku yang demokratis serta bertanggung jawab atas dirinya sendiri, maupun orang lain. Proses penerapan nilai karakter dalam IPS dilaksanakan dengan meneladani pendidik melalui kegiatan belajar mengajar (Utomo Eko, 2018). Maka dalam kaitannya dengan nilai-nilai dalam pembelajaran IPS, seorang pendidik hendaknya membimbing mengarahkan peserta didik untuk bertingkah laku sesuai dengan nilai-nilai yang berlaku. Selain itu pendidik perlu memberikan motivasi peserta didiknya untuk bersikap baik, karena karakter yang baik dapat menciptakan pengalaman bagi dirinya di kelas maupun lingkungan sosialnya dalam kehidupannya sehari-hari. 
Tabel 1. Pembelajaran IPS dengan HOTS

\begin{tabular}{ll}
\hline Indikator & Tingkat KKO \\
\hline - Menyebutkan dengan benar 3 faktor penyebab keragaman di Indonesia & 1 \\
& \\
- Menulis informasi penting dalam teks bacaan "Rumah Adat Suku & $2,6,5$ \\
& Manggarai" \\
- Membuat narasi tentang salah satu rumah, pakaian, dan tarian adat \\
setempat di Indonesia
\end{tabular}

Keterangan:

Buku Tema Kelas IV Tema 7 (Indahnya Keragaman di Negeriku)

Kompetensi Dasar IPS 3.2 dan 4.2

Tingkat KKO; Tingkat Kompetensi Kata Kerja Operasional Ranah Kognitif C1-C6.

Pembelajaran $3 \& 4$

Halaman Buku Guru; 19, 55, 58, dan 59,

Halaman Buku Siswa; 27, 64, 70, dan 77.

Tabel 2. Pembelajaran IPS dengan 4C

\begin{tabular}{ll}
\hline Indikator & 4C \\
\hline - Menyebutkan dengan benar 3 faktor penyebab keragaman di Indonesia. & Creativity \\
- Menulis informasi penting dalam teks bacaan "Rumah Adat Suku & Critical \\
$\quad$ Manggarai" & Thinking, \\
- Membuat narasi mengenai salah satu rumah, pakaian dan tarian adat & Collaboration \\
& \\
\hline
\end{tabular}

Keterangan:

Buku Tema Kelas IV Tema 7 (Indahnya Keragaman di Negeriku)

Kompetensi Dasar IPS 3.2 dan 4.2

Pembelajaran 3 \& 4

Halaman Buku Guru; 17, 54, dan 57.

Halaman Buku Siswa; 20, 65, dan 77. 
Tabel 3. Pembelajaran IPS dengan Karakter

\begin{tabular}{ll}
\hline Indikator & Karakter \\
\hline - Menyebutkan dengan benar 3 faktor penyebab keragaman di Indonesia. & $\begin{array}{l}\text { Percaya Diri, } \\
\text { Berani } \\
\text { - Menulis informasi penting yang ada dalam teks bacaan "Rumah Adat } \\
\text { Suku Manggarai" }\end{array}$ \\
$\begin{array}{l}\text {-Mandiri } \\
\text { - Membuat narasi mengenai salah satu rumah, pakaian, dan taria adat }\end{array}$ & -Percaya diri \\
\end{tabular}

Keterangan:

Buku Tema Kelas IV Tema 7 (Indahnya Keragaman di Negeriku)

Kompetesi Dasar IPS 3.2 dan 4.2

Pembelajaran $3 \& 4$.

Halaman Buku Guru; 19, 55, dan 97.

Halaman Buku Siswa; 27, 67, dan 125.

\section{KESIMPULAN}

Penulisan ini membahas tentang pembelajaran IPS di SD/MI dalam kurikulum 2013. Kompetensi dasar yang ada pada materi IPS memuat beberapa aspek yang dapat mengembangkan potensi peserta didik, serta melatih peserta didik dalam memiliki berbagai kecakapan seperti kecakapan intelektual, karakter, sosial, kreativitas, dan spiritual. Berdasarkan penelitian tersebut maka kesimpulannya yaitu pembelajaran IPS di SD/MI dalam kurikulum 2013 merupakan perkumpulan dari berbagai komponen seperti; struktur keilmuan IPS di SD/MI, karakteristik perkembangan peserta didik, HOTS (bigher order thinking skill), literasi finansial, literasi budaya dan kewargaan, literasi digital, dan pendidikan karakter. Karena keterbatasan peneliti, untuk penelitian lanjutan mungkin dapat mengkaji buku teks yang memuat kompetensi dasar dalam disiplin ilmu lainnya pada kurikulum 2013. Selain itu penelitian selanjutnya hendaknya lebih menekankan pada soal-soal HOTS dalam buku teks tema di SD/MI.

\section{REFERENSI}

Anshori, S. (2016). Kontribusi Ilmu Pengetahuan Sosial Dalam Pendidikan Karakter. Edueksos: Jurnal Pendidikan Sosial \& Ekonomi, 3(2), 59-76.

Budiarti, Y. (2015). Pengembangan Kemampuan Kreativitas Dalam Pembelajaran. Promosi (Jurnal Pendidikan Ekonomi), 3(1), 61-72.

Fanny, A. mahya. (2019). Implementasi Pembelajaran Berbasis HOTS dalam Meningkatkan Kemampuan Analisis Mata Kuliah Pembelajaran IPS di Sekolah Dasar. Jurnal Pendidikan 
Dasar, 10(2), 44-95.

Funali, M. (2014). Meningkatkan Hasil Belajar Siswa pada Mata Pelajaran IPS dengan Menggunakan Model Pembelajaran Kolaborasi pada Siswa Kelas V SDN I Siboang. Jurnal Kreatif Tadulako Online, 4(1), 47-80.

Ginanjar, A., Noviani, A. ., Aisyah, N. S., Fredi, H., \& Adila, B. . (2019). Implementasi Literasi Digital dalam Proses Pembelajaran IPS di SMP Al-Azhar 29 Semarang. Harmoni, 4(2), 99-105.

Herijanto, B. (2012). Pengembangan CD Interaktif Pembelajaran IPS. Materi Bencana Alam. Journal Of Education Social Studies, 1(1), 8-12.

Indraswati, D., Marhayani, D. A., Sutisna, D., Widodo, A., \& Maulyda, M. A. (2020). Critical

Thinking Dan Problem Solving Dalam Pembelajaran Ips Untuk Menjawab Tantangan Abad 21. Sosial Horizon: Jurnal Pendidikan Sosial, 7(1), 12.

Janawi. (2019). Memahami Karakteristik Peserta Didik dalam Proses Pembelajaran. Tarbawy: Jurnal Pendidikan Islam, 6(2), 68-79.

Kementerian Pendidikan dan Kebudayaan. (2017a). Materi Pendukung Literasi Budaya dan Kewargaan. Jakarta: Kemendikbud.

Kementerian Pendidikan dan Kebudayaan. (2017b). Materi Pendukung Literasi Digital. Jakarta: Kemendikbud.

Laila, V., \& Hadi, S. (2019). Pelaksanaan Pendidikan Literasi Finansial pada Siswa Sekolah Dasar, (2006), 1491-1495.

Latifah, S. (2014). Integrasi Pendidikan Karakter dalam Pembelajaran Di Sekolah. Jurnal Ilmiah Pendidikan Fisika Al-Biruni, 3(2), 24-40.

Meldina, T., Agustin, A., \& Harahap, S. H. (2020). Integrasi Pembelajaran IPS pada Kurikulum 2013 di Sekolah Dasar Institut Agama Islam Negeri Curup Sekolah Dasar Negeri 10 Pasaman PENDAHULUAN Pendidikan semestinya sudah dilakukan sedari dini yaitu dengan melakukan pendidikan dasar . Pada Undang-undang No, 4(1).

Munastiwi, E. (2019). Manajemen Model Pembinaan Kelompok Guru Paud Model 'MultiWorkshop'. Al-Athfal, 4(1), 41-50.

Nugroho, S. (2020). Klik Bervisi: Kelompok Literasi Kekinian Berkarya, Berinovasi, dan Visioner. Bandung: Tata Akbar.

Nurdyansyah, \& Fahyuni, E. F. (2016). Inovasi Model. Nizmania Learning Center. Sidoarjo: Nizamia Learning Centre.

Peraturan Menteri Pendidikan Kebudayaan 2016 No. 16. (n.d.). Standar Kompetensi Lulusan 
Pendidikan Dasar dan Menengah. Jakarta: Permendikbud.

Prastowo, A. (2015). Menyusun Rencana Pelaksanaan Pembelajaran (RPP) Tematik Terpadu: Implementasi Kurikulum 2013 untuk SD/MI. Jakarta: Prenada Media Group.

Rahayuningsih, S., \& Rani, J. (2019). Grup Hots Gender. Ponorogo: Uwais Inspirasi Indonesia.

Rahmad. (2016). Kedudukan Ilmu Pengetahuan Sosial (IPS) pada Sekolah Dasar. Muallimuna: Jurnal Madrasah Ibtidaiyah, 2(1), 67-78.

Rapih Subroto. (2016). Pendidikan Literasi Keuangan Pada Anak: Mengapa dan Bagaimana? Scholaria, 6(2), 14-28.

Rosidatun. (2018). Model Implementasi Pendidikan Karakter. Gresik: Caremedia Communication.

Saharuddin, \& Mutiani. (2020). Strategi Pembelajaran IPS: Konsep dan Aplikasi. Banjarmasin:

Program Studi Pendidikan IPS Fakultas Keguruan dan Ilmu Pendidikan Universitas Lambung Mangkurat.

Samio. (2018). Aspek-Aspek Pertumbuhan dan Perkembangan Peserta Didik. . Best Journal (Biology, Education, Science, \& Technology), 1(2), 36-43.

Septikasari, R., \& Frasandy, R. N. (2018). Keterampilan 4C Abad 21 dalam Pembelajaran

Pendidikan Dasar. Tarbiyah Al-Awlad, VIII(2), 112-122.

Setiana, N. (2014). Pembelajaran Terintegrasi Dalam Konteks Kurikulum 2013. EduHumaniora | Jurnal Pendidikan Dasar Kampus Cibiru, 6(2), 95-108.

Setiawan, B. (2020). Pengembangan Mata Pelajaran untuk Memperkuat Literasi Budaya dan Kewargaan. Jurnal Masyarakat Indonesia, 4(1), 80-92.

Simamarta, J., Lidia, S., \& Rahmi, R. (2020). Pembelajaran STEM Berbasis HOTS dan Penerapannya. Jakarta: Yayasan Kita Menulis.

Sinambela, P. nauli josip mario. (2013). Kurikulum 2013 , Guru , Siswa , Afektif , Psikomotorik , Kognitif. e-journal Universitas Negeri Medan, 6, 17-29.

Siska, Y. (2016). Konsep Dasar untuk SD/MI. Yogyakarta: Garudhawaca.

Subadi, T., Priyono, K., Dahroni, \& Musyiyam, M. (2015). Implementasi Pembelajaran IPS Berbasis Kurikulum 2013 melalui Lesson Study di Sekolah Muhammadiyah Kartasura. Jurnal Warta, 18(1), 62-76.

Surahman, E., \& Mukminan. (2017). eran Guru IPS sebagai Pendidik dan Pengajar dalam Meningkatkan Sikap Sosial dan Tanggung Jawab Sosial Siswa SMP. Harmoni Sosial: Jurnal Pendidikan IPS, 4(1), 1-13.

Susanto, A. (2014). Pembelajaran IPS di Sekolah Dasar. Jakarta: Prenada Media Group.

Sutrisna, E. (2012). Strategi Guru dalam Pembelajaran IPS (Studi Eksploratif Pelaksanaan 
Pembelajaran IPS di SMP Wiayah Kabupaten Pati. Journal Of Education Social Studies, 1(1), 48-54.

Syamsunardi, \& Nur, S. (2019). Pendidikan Karakter dalam Keluarga dan Sekolah. Sulawesi Selatan: Yayasan Ahmar Cendekia Indonesia.

Utomo Eko, P. (2018). Internalisasi Nilai Karakter Gotong Royong dalam Pembelajaran IPS untuk Membangun Modal Sosial Peserta Didik. Jurnal Teori dan Praksis Pembelajaran IPS, 3(2), 95-102.

Yukarista. (2019). Literasi: Solusi Terbaik untuk Mengatasi Problematika Sosial di Indonesia. Sukabumi: CV Jejak, Anggota IKAPI. 